\title{
THE EFFECT OF THE IMPLEMENTATION OF ULTRASOUND IN ENZYME SEPARATION \\ ${ }^{1}$ K. Keçeci, ${ }^{2}$ B. Lemmer, ${ }^{2} S z$. Kertész, ${ }^{2} G$. Keszthelyi-Szabó, ${ }^{2} Z s$. László, ${ }^{2} C$. Hodúr \\ ${ }^{1}$ Abbant, Izzet Baysal University, Gölköy Kampüsü, Bolu, Turkey \\ ${ }^{2}$ University of Szeged, 7. Mars sq. H-6724 Szeged, Hungary \\ e-mail: hodur@mk.u-szeged.hu
}

\begin{abstract}
Enzymes are biological catalysts that generally are designed to do one job well, but to do one job only. Therefore, the enzymes that catalyze the hydrolysis of cellulose to sugar do not break down the sugars. Enzymatic hydrolysis processes have been under development for only 10 years. The important research issues include understanding the processes necessary to render the crystalline cellulose easily digestible, understanding and improving the basic mechanisms in the hydrolysis step, and developing better and less expensive enzymes. The other way to make a process less expensive may be the recycling of enzymes. The essential unit operation in the bioethanol production is the cellulose enzymatic degradation, so the question of recycling is very important.

In our work the sonication assisted ultrafiltration was investigated as a potential method for enzyme recycling. The results showed the ultrasound effects the permeate flux since the resistance is reduced by the sonication. The sonicated enzyme keeps its activity so the recycling mechanism might be used for bioethanol production.
\end{abstract}

Keywords: enzyme recovery, ultrafiltration, sonication, bioethanol

\section{INTRODUCTION}

Due to the limited power of the world, new energy sources have begun to research $[1,2]$, in this topic, alternatively biomass energy is considered. One of the most immediate and important applications of biomass energy systems could be in the fermentation of ethanol from biomass. Biomass is seen as an interesting energy source for several reasons, for example greenhouse gas emission, sustainability or energy-safety[3]. There have been many studies on the evaluation of waste; especially ethanol production which have of great importance in recent times. Many industrial waste, urban sewage, solid waste and agro-food waste have been used as a raw material to produce ethyl alcohol. The aims of using wastes for alcohol production is: satisfying the fast growing needs, using agricultural and industrial wastes as substrate, and make a solution to the environmental pollution problem and ultimately, obtaining a product of economic value.

Biological conversion of cellulose in wastes to fermentable sugar with cellulase appears to be a feasible approach to such recycling. Cellulose is the most abundant carbohydrate polymer in wastes from forest products agriculture, fruits, and vegetables [4]. In ethanol production the delignification of cellulose is the basic element following depolymerisation of carbohydrate polymers to free sugars via enzymes and at the end the fermentation of these sugars $[5,6,7]$. The low hydrolytic conversion rates and the high cost of enzymes which make the implementation of overall process uneconomical are important criteria of producing bioethanol $[8,9]$. Because of the heterogeneous nature of the substrate it was difficult to obtain information about the enzymatic hydrolysis mechanism. Expansion of fermentation technologies to the low-cost lignocellulosic biomass holds a great potential for in terms of energy reserves for future. Enzymatic hydrolysis of cellulose has many advantages like milder reaction conditions, higher product yields, fewer side reactions, less energy demand and less reactor resistance to pressure and corrosion [10]. Enzymes are also environment-friendly and non-toxic or corrosive. However commercial application of enzymatic hydrolysis of cellulose has been deterred by the high cost of enzymes, slow reaction rate and lack of an effective reactor system for the complex heterogeneous nature of the reaction in a solid-liquid system. 
The main force of membrane technology is the fact that it works without the addition of chemicals, with a relatively low energy use and easy and well-arranged process conductions. Membrane filtration systems can be managed in either dead end flow or cross flow. The purpose of the optimisation of the membrane techniques is the achievement of the highest possible production for a long period of time, with acceptable pollution levels. The membrane separation process is based on the presence of semi permeable membranes. Besides the advantages, it has some negative features like high purchase price of the membrane. Clearly the high purchase price of membranes has sparked interested in developing cheaper material. The other one of disadvantages; residue (very concentrated filtrate) has to be collected or further treated. Membrane modules often cannot operate at much above room temperature. This is again related to the fact that most membranes are polymer-based, and that a large fraction of these polymers do not maintain their physical integrity at much above $100^{\circ} \mathrm{C}$. This temperature limitation means that membrane processes in a number of cases cannot be made compatible with chemical processes conditions very easily. So temperature and pressure were controlled at per point. In addition to filtering, ultrasound attached filtering was used. This technique is based on ultrasound irradiation within the liquid, owing to the combined effect of cavitation, acoustic streaming, micro-streaming, micro-streamers, and micro-jets. Ultrasonic-assisted flat-sheet membrane filtration processes have been reported to demonstrate the effectiveness on enhancing permeate flux. High productivity and reasonable product purity are required for ultrafiltration. Due to these features ultrafiltration has been established as one of the main separation and purification techniques for the enzyme industry in addition to the salt precipitation, spray drying, lyophilisation, etc. [11]. Ultrafiltration has advantages also like fouling and concentration polarization in cross-flow ultrafiltration faced by the enzyme industries [12]. The decrease in permeate flux and the increase in pressure drop due to fouling can adversely impact the membrane filtration efficiency $[13,14,15]$.

In our work an enzyme recycling method was investigated for enhancing and making cheaper the bioethanol production. The aim of our work was to measure the effect of the ultrasound on membrane fouling, to insure is there any effect of the transducer distance on the permeate flux. Kept enzyme activity is needed for recycling, so the enzyme activity was measured followed sonication by paper-cellulose method.

\section{MATERIALS AND METHODS}

\subsection{Enzymes}

Sigma - Aldrich enzymes were used for our work. Cellobiase from Aspergillus niger, C6105 and Cellulase from Trichoderma reesei ATCC 26921, C2730). The solution contained $5+5 \mathrm{~cm}^{3}$ of cellulose and cellobiase in $1 \mathrm{~L}$ solution.

\subsection{Glucose content}

The glucose content was determined spectrophotometrically with using of the 3,5-dinitrosalicylic acid (DNSA) method after calibration. This method test for the presence of free carbonyl group $(\mathrm{C}=\mathrm{O})$, the socalled reducing sugars. $300 \mu \mathrm{L}$ sample and $300 \mu \mathrm{L}$ DNSA was collected in an Eppendorf tube. The mixtures were heated at $90^{\circ} \mathrm{C} 15$ minutes to develop the red-brown colour. After that, $100 \mu \mathrm{L} 40 \% \mathrm{KNa}$-Tartrate was added in all samples. Simultaneously absorbance were recorded with a spectrophotometer at $475 \mathrm{~nm}$ (zeroing with a blank sample, calibration with known concentration glucose solutions.)

\subsection{Protein Content}

Protein content is investigated with total Kjeldahl nitrogen method. Total nitrogen or TKN is the sum of organic nitrogen, ammonia $\left(\mathrm{NH}_{3}\right)$, and ammonium $\left(\mathrm{NH}_{4}{ }^{+}\right)$in the chemical analysis of soil, water, or wastewater. TKN is often used as a surrogate for protein in food samples. The conversion from TKN to protein depends on the type of protein present in the sample and what fraction of the protein is composed of nitrogenous amino acids. 
In Kjeldahl tubes $5 \mathrm{~g}$ sample and a catalyst tablet was added. One tablet contains 3,5g KSO and 3,5mg Se. $25 \mathrm{ml} \mathrm{H}_{2} \mathrm{SO}_{4}$ was added in all tubes and thereafter tubes were put Kjehdahl device at $400^{\circ} \mathrm{C}$ during 2 hours. When they were cold, protein content was measured by Kjeltec 2300 .

\subsection{Membrane Filtration}

Separation was carried out with a stirred ultrafiltration batch device with $300 \mathrm{~cm}^{3}$ capacity, equipped with a $40 \mathrm{~cm}^{2}$ polyethersulphone (PES) membrane with a cut-off value of $10 \mathrm{kDa}$. During filtration, the sample was mixed continuously with a magnetic stirrer $(350 \mathrm{rpm})$, or ultrasound was applied. When ultrasound was used, the transducer distance from the membrane surface was set to 2,3 or $4 \mathrm{~cm}$.

Both the selectivity and the efficiency are shown by the retention $(\mathrm{R})$ :

$$
\mathrm{R}=\left[1-\mathrm{c} \cdot \mathrm{c}_{0}^{-1}\right] \cdot 100(\%)
$$

where $c$ is the concentration of the permeate $(\%)$ or $\left(\mathrm{mg} \mathrm{dm}^{-3}\right)$ and the $c_{0}$ is the concentration of the feed $(\%)$ or $\left(\mathrm{mg} \mathrm{dm}^{-3}\right)$. The retention was calculated from data of protein content.

\subsection{Total Organic Carbon (TOC)}

TOC was measured by Teledyne Tekmar Torch automatic TOC analyzer. During the measurement $750{ }^{\circ} \mathrm{C}$ burning temperature were used. The injected sample was $100 \mu \mathrm{L}$. The machine uses phosphoric acid to wipe non-organic carbon from the samples. The used method uses $500 \mu \mathrm{L}$ of phosphoric acid. The samples $\mathrm{CO}_{2}$ volume was detected by infrared (NDIR) detector. Using the pre-calibration the software makes a report from the measurement. The solution ratio of the samples was 1:25. 3 parallel measurements were used for each sample.

\subsection{Sonication effect factor and fouling ratio}

Sonication effect factor (SEF\%) and fouling ratio (FR\%) were calculated with below formulas:

$$
\begin{aligned}
\mathrm{SEF} \% & =\left[\left(\mathrm{J}_{\mathrm{US}}-\mathrm{J}\right) \mathrm{J}^{-1}\right] \cdot 100 \\
\mathrm{FR} \% & =\mathrm{J}_{\mathrm{W} 1} \cdot \mathrm{J}_{\mathrm{W} 2}{ }^{-1} \cdot 100
\end{aligned}
$$

Where $\mathrm{J}_{\mathrm{US}}$ is flux when US was applied, $\mathrm{J}$ is flux when neither ultrasound, nor stirring was applied, $\mathrm{J}_{\mathrm{w} 1}$ is water flux before and $\mathrm{J}_{\mathrm{w} 2}$ is water flux after filtering model solvent.

\section{RESULTS}

At first water flux was measured under different conditions. The effects of used stirrer and ultrasound were investigated (Fig. 1). US 2/3/4 cm means only ultrasound was used and the transducer distance was 2,3 or $4 \mathrm{~cm}$. 


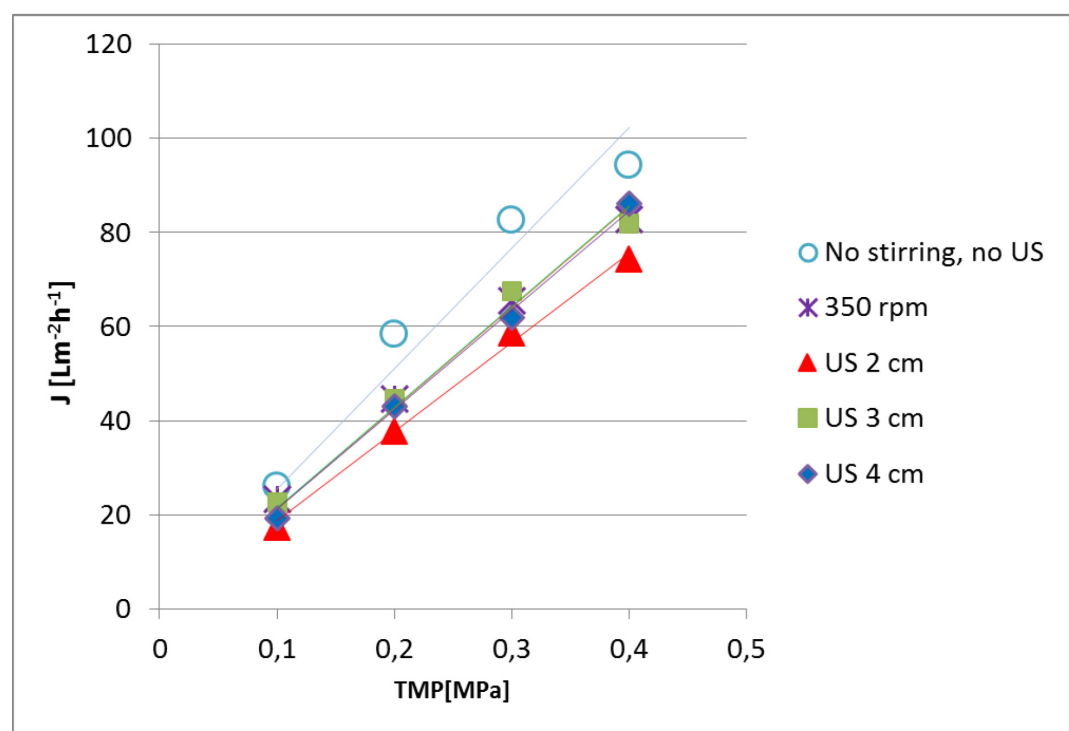

Figure 1. The flux rate under pressures with distilled water

(US 2/3/4 cm means that only ultrasound was used and the transducer distance was 2,3 or $4 \mathrm{~cm}$.)

It clearly shows that flux increased with the transmembrane pressure (TMP) regardless of stirring or ultrasonication. It should be observed also that when TMP is over $0.3 \mathrm{MPa}$, the "no stirring no us" method reaches the highest flux actually exceeded the flux of sonication.

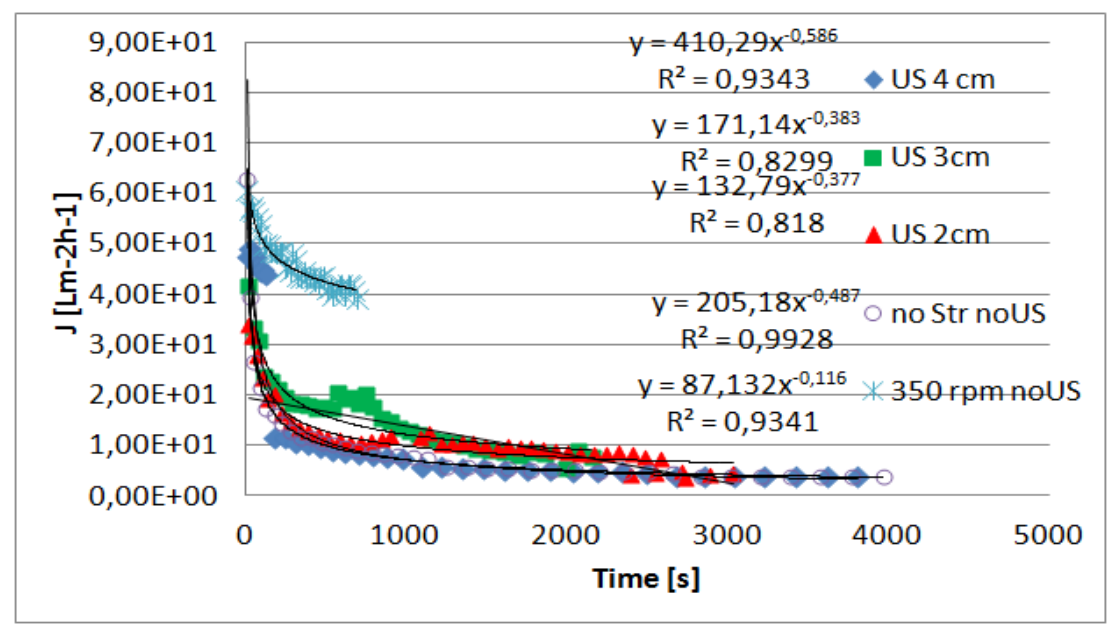

Figure 2. The overall permeation flux vs. time under different treatment types

(US 2/3/4 cm means that only ultrasound was used and the transducer distance was 2,3 or $4 \mathrm{~cm}$.

)

The flux value of samples with $350 \mathrm{rpm}$ without ultrasound $\left(\mathrm{J}_{\text {eqvil }}=43 \mathrm{Lm}^{-2} \mathrm{~h}^{-1}\right)$ is the highest. The other samples gave very similar result, the "no stirring no ultrasound" (no Str no US) $\left(\mathrm{J}_{\text {eqvil }}=4 \mathrm{Lm}^{-2} \mathrm{~h}^{-1}\right)$ and the sonication from $4 \mathrm{~cm}$ distance $\left(\mathrm{J}_{\text {eqvil }}=4,3 \mathrm{Lm}^{-2} \mathrm{~h}^{-1}\right)$ have quite the same values. Since the fluxes are so similar, resistance and the rejection values were calculated to evaluate the processes. 


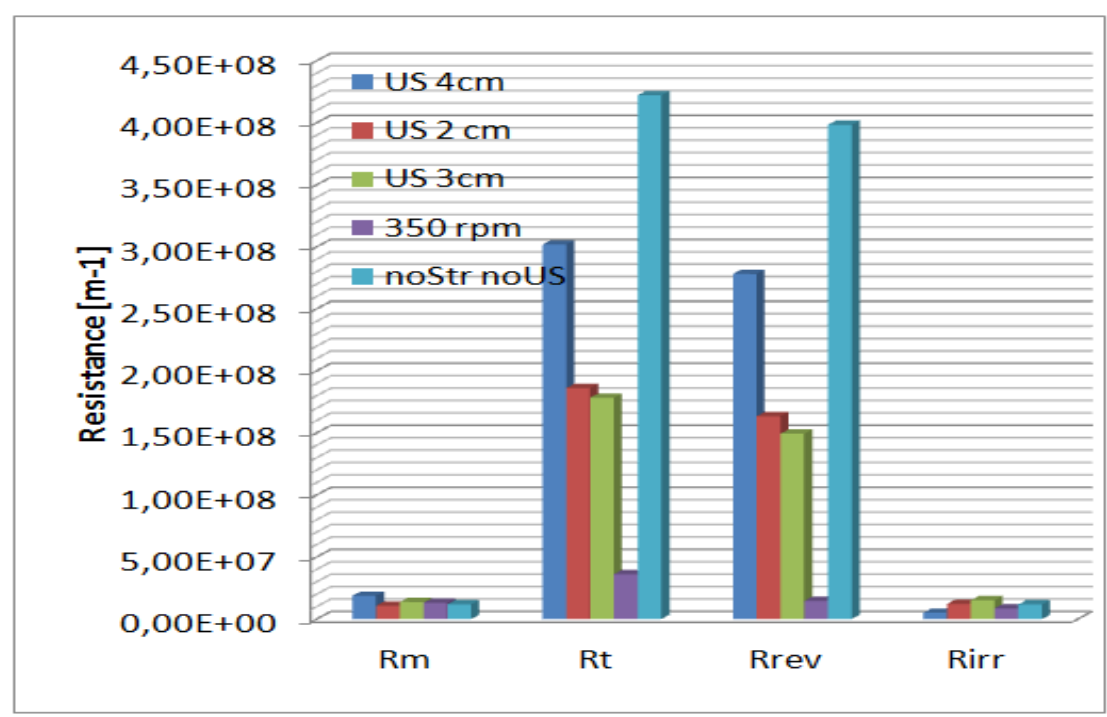

Figure 3. Resistances at different methods

(Rm, Rt, Rrev and Rirr means in order membrane, total, reversible and irreversible resistance)

The Fig. 3 clearly shows that reversible resistance was higher than irreversible resistance in any cases, and it gives the main part of the total resistance. Measurement made without ultrasound and without stirring has the highest total resistance and reversible resistance also. If measurement system used ultrasound effect the values reduced. The smallest total resistance value is measured at stirring effect, and the $2 \mathrm{~cm}$ distance gives the best result, the smallest value among the sonicated samples. The other distances might be far a little bit to develop a real effective micro-jet action.

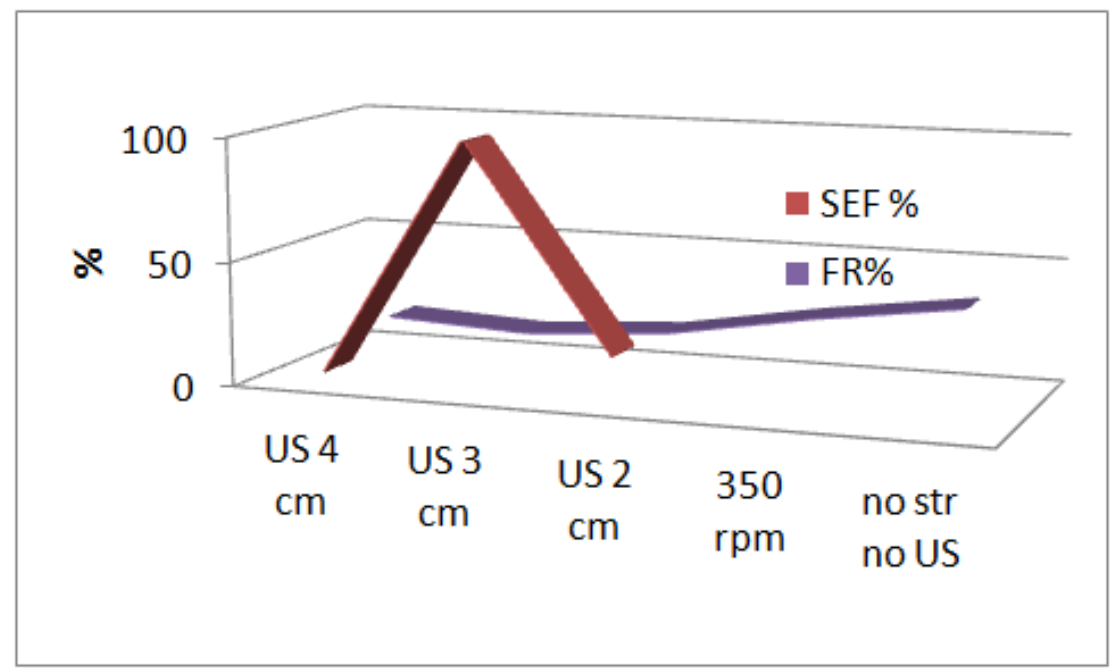

Figure 4. Sonication effect (SEF) and Fouling ratio under different conditions (US 2/3/4 cm means that only ultrasound was used and the transducer distance was 2,3 or $4 \mathrm{~cm}$.) 
But when the sonication effect (SEF) calculated on (1) was investigated, and the fouling ratio (FR) calculated on (2) (Fig. 4) the advantages of sonication and the advantages of the $3 \mathrm{~cm}$ distance for sonication could be realised. It would be explained the mechanism of cavitation, i.e. the real effective micro flow above the membrane surface could be realised, could be built up at the distance of $3 \mathrm{~cm}$. The 4 $\mathrm{cm}$ distance seemed to be too far from the membrane effective "bubbling". On the other hand the $2 \mathrm{~cm}$ distance is too close to the membrane, that's why optimal flowing profile couldn't be formed.

Fig. 5 shows no significant difference in the retention of sonicated samples, and these have the best values, but there is a big difference among the applied methods as well. It is very interesting and reinforced the claim that the rejection depends on not only the cut off value of the membrane but the structure of boundary layer as well.

There is the same tendency when the retention is calculated on protein content or the TOC content as well. The real value of the retention is different as cause, since the Kjehdlahl method measure mainly the protein originated $\mathrm{N}$ content, meanwhile the TOC method measures the carbon content of the whole organic so the small organic components as well.

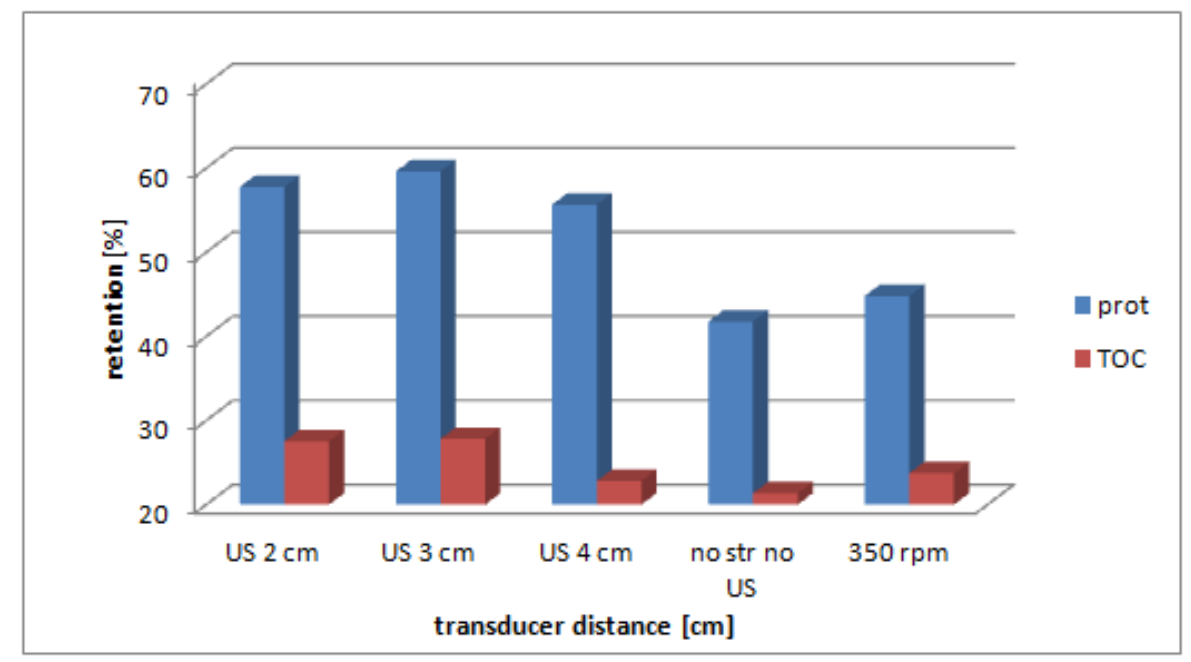

Figure 5. Effect of retention at different methods and different transducer distances based on protein content and TOC (US 2/3/4 cm means that only ultrasound was used and the transducer distance was $2,3 \mathrm{or} 4 \mathrm{~cm}$.)

As the ultrasound has an effect on the flux, i.e. the structure of the boundary layer above membrane, it might have effect on the enzyme molecules themselves. Some paper reports positive effect of ultrasound on the enzyme activity but the structure of enzyme is very sensitive, the configuration of the molecule is the key factor for its activity. In the Fig. 6 is shown the glucose concentration versus time i.e. the enzyme activity values of the sonicated and separated enzymes. 


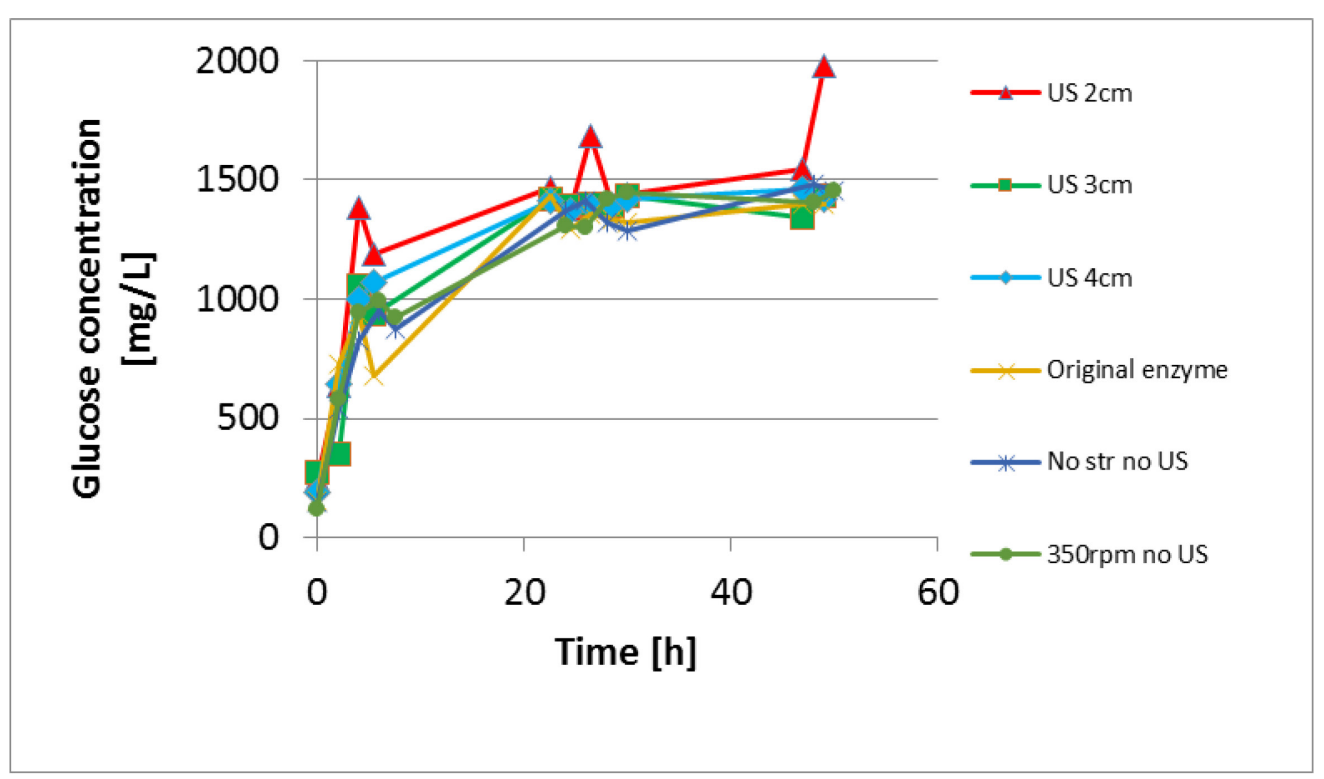

Figure 6. Enzyme activities of sonicated enzymes

(US 2/3/4 cm means that only ultrasound was used and the transducer distance was 2,3 or $4 \mathrm{~cm}$.)

The data show there is no enzyme hurdling, even more the sonicated enzymes have a little bit higher activity than the original one, but the transducer distance has no significant effect on the enzyme activity.

\section{SUMMARY}

In this study, effect of ultrasound was investigated on enzyme separation by membrane filtration. The effect of transducer distance was studied and the data were compared with data of the filtration without ultrasound, and filtration with stirring only.

As basic step the permeate flux was measured with distilled water, after that with model solvent that is made from prepared enzyme from Sigma-Aldrich. Measurements were done on a laboratory membrane filtration cell. The effect of US on water flux and model solvent were compared filtering with/without stirring. The retentate was used for enzyme activity tests. The efficiency of enzyme after fermentation was characterized by glucose yield measured by photometric glucose assay.

The flux of ultrafiltration was higher applied low energy and frequency ultrasound than without ultrasound. The sonication effect was well developed at $3 \mathrm{~cm}$ distance of transducer. The reversible resistance was the main characteristic element of the total resistance, the irreversible resistance was much smaller than reversible which is a very important fact related to the industrial application. Sonication decreased the reversible retention only. The retention based on protein content was higher than $50 \%$ in any sonicated cases meanwhile the control and stirred samples showed less than $40 \%$ as a retention value. The enzyme activity was kept despite sonication, even more these samples showed higher glucose concentration at the cellulose test than the control and stirred samples.

Overall the sonication is a very useful co-method together the ultrafiltration for enzyme separation.

ACKKOWLEDGEMENT: The authors are grateful for the financial support provided by the OTKA 105021 project funded by the Hungarian Scientific Research Fund. 


\section{REFERENCES}

[1] A. E. Wheals, Fuel ethanol after 25 years, Trends Biotechnol, 17, (1999), pp. 482-486

[2] J. Zaldivar, Fuel ethanol production from lignocellulose: a challenge for metabolic engineering and process integration, Appl. Microbiol. Biotechnol., 56, (2001), pp. 17-34

[3] M. Hoogwijka, A. Faaija, R. van den Broeka, G. Berndesb, D. Gielenc, W. Turkenburga, Exploration of the ranges of the global potential of biomass for energy, Biomass Bioenergy, 25, (2003), pp. 119133

[4] L. R. Lynd, Microbial Cellulose Utilization: Fundamentals and Biotechnology, American Society for Microbiology 66, (2002), pp. 506-577

[5] H. Esterbauer, M. Hermann, Production of Trichoderma cellulase in laboratory and Pilot Scale, Bioresource Technology, 36, (1991) pp. 51-65

[6] M. Ábel, G. Keszthelyi-Szabó, D. Vitay, C. Hodúr, Membrane separation and sonication in bioethanol production, Desalination and water treatment 1-6 (2014)

[7] S. Beszédes, A. Tachon, B. Lemmer, M. Ábel, G. Szabó, C. Hodúr, Bio-fuels from cellulose by microwave irradiation, Annals of Faculty of Engineering Hunedoara, Annals of Faculty of Engineering, 10 (2), (2012) pp. 43-48

[8] L.T. Fan, Mechanism of the Enzymatic Hydrolysis of Cellulose: Effects of Major Structural features of Cellulose on Enzymatic Hydrolysis, Biotechnology and Bioengineering, 65, (1980), pp. 177-190

[9] L. Jeewon, Biological conversion of lignocellulosic biomass to ethanol, Journal of Biotechnology 56, (1997), pp. 1-24

[10] S. Marques, Conversion of recycled paper sludge to ethanol by SHF and SSF using Pichia stipitis, Biomass and Bioenergy, 32, (2008), pp. 400-406

[11] Sz. Szélpál, O. Poser, M. Ábel, Enzyme recovery by membrane separation method from waste products of the food industry, Acta Technica Corviniensis - Bulleitn of Engineering, 6 (2), (2013) pp. 149-154

[12] A. Suki, A.G. Fane, Flux decline in protein ultrafiltration, J. Membr. Sci., 21, (1984), pp. 269-283

[13] C. Cabassud, Air sparging in ultrafiltration hollow-fibers: relationship between flux enhancement, cake characteristics and hydrodynamic parameters, J. Membr. Sci., 181, (2001), pp. 57-69

[14] T. Chung, Effect of dope flow rate on the morphology, separation performance, thermal and mechanical properties of ultrafiltration hollow fibre membranes, J. Membr. Sci., 157, (1999), pp. 2336

[15] R. J. Wakeman, Electroacoustic cross-flow microfiltration, Filtr. Sep., 29, (1992), pp. 425-432 